\title{
THE HISTORIC DEVELOPMENT OF THE EVOLUTIONARY IDEA
}

$\mathrm{QH}$

361

.P48

1923 ANTH

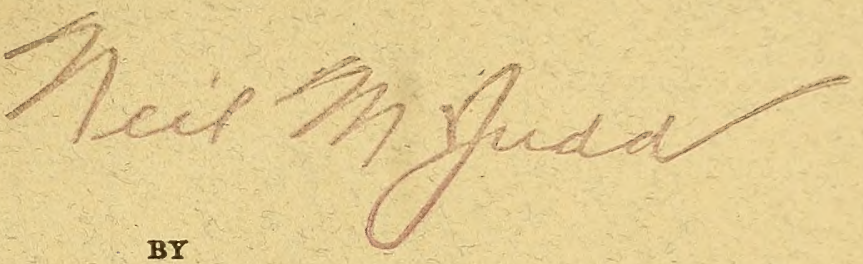

BRANISLAV PETRONIEVICS

tontslon of ARChEOLOOX

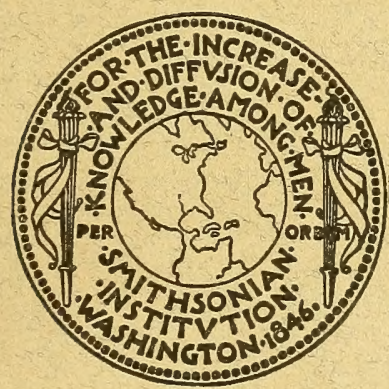

(Publication 2687)

WASHINGTON

GOVERNMENT PRINTING OFFICE

1928 



\title{
THE HISTORIC DEVELOPMENT OF THE EVOLUTIONARY IDEA
}

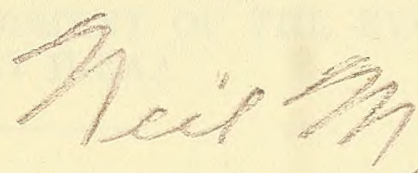

BY

\author{
BRANISLAV PETRONIEVICS
}

FROM THE SMITHSONIAN REPORT FOR 1921, PAGES 325-334

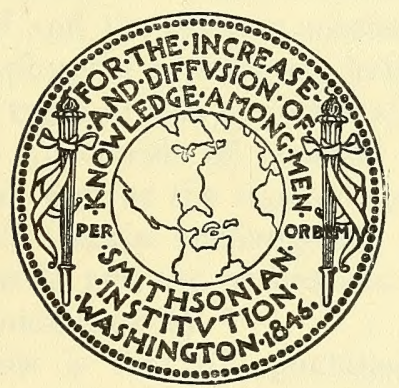

(Publication 2687)

WASHINGTON

GOVERNMENT PRINTING OFFICE 


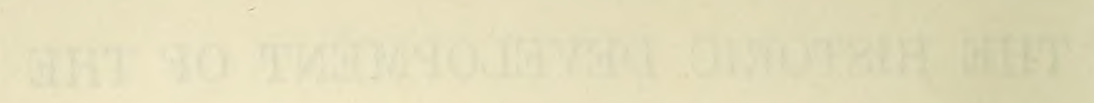

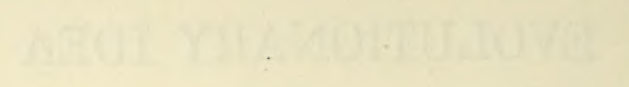

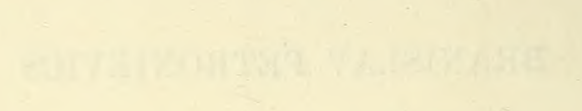

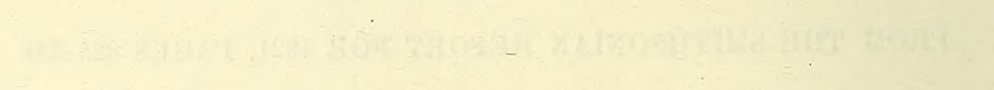

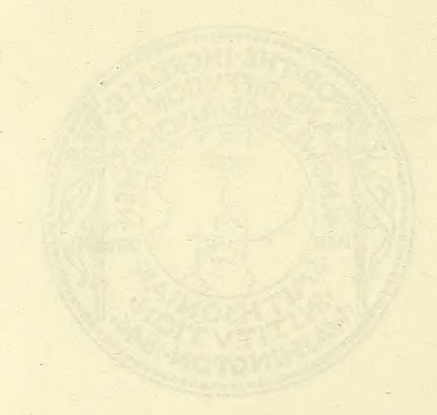

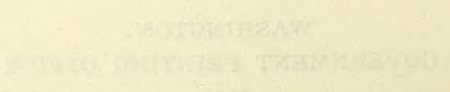




\section{THE HISTORIC DEVELOPMENT OF THE EVOLUTION- ARY IDEA. ${ }^{1}$}

By Branislat Petronievics.

This historical outline must be very short, and I will only indicate in a few words the main features of the doctrines of evolution held by different thinkers. I am making this outline particularly because I wish to enable my readers to avoid the mistakes which are so often found in even the best known works on this subject. These books have been written either by philosophers who were not always in a position to really understand the meaning of the scientific doctrines of evolution, or by scientists who, on their part, were unable to thoroughly grasp the meaning of the corresponding ideas of the philosophers.

In order to make perfectly clear the simple meanings of the different theories about the origin of the world and of things in it, I must first briefly state the principal hypotheses about this origin which are considered tenable. There are four of them. The first is the hypothesis of the eternality of things, according to which the inorganic world is eternal and the organic species also eternal and unchangeable (the metaphysical systems of Aristotle and of Spinoza are the representative types of this hypothesis).

The second is that hypothesis of creation which conceives that the inorganic world as well as the organic species were created by God, but, once created, remain unchangeable (this is the orthodox hypothesis of the Church, and the naturalists. Cuvier and Agassiz are the best known sponsors of it).

The third hypothesis is that of spontaneous general creation; namely, that the inorganic world was produced out of sheer nothingness and that organized beings were immediately formed out of a transformation of inorganic matter. (The doctrine of Buddha is the only representative of this hypothesis concerning the origin of the inorganic world, while there are several Greek philosophersAnaximander, Empedocles, Epicurus-who teach the spontaneous generation of all organic beings, however complex.)

\footnotetext{
${ }^{1}$ Translated by permission from “L'Evolution Universelle," by Branislav Petronievics, of which it forms the first chapter. Librairie Félix Alcan, Paris, 1921.
} $101257-23-22$ 
Lastly, the fourth hypothesis is that of evolution, according to which the inorganic world as it exists to-day comes from a primordial state quite different from its present condition, and the organic species have been developed by a gradual transformation from inferior to superior species. (Among scientists, Laplace is the best known representative of the theory of the evolution of the inorganic world, Lamarck and Darwin, of the evolution of the organic world; among philosophers, Kant is the most noted representative of the doctrine of inorganic world evolution, and Spencer, Hartman, and Bergson of the idea of the evolution of the organic world.)

In order to make these four hypotheses more easily understood, I am placing them in a diagram which will show plainly their mutual relationships.

\section{Diagram.}

A. Things have no origin

I. Hypothesis of eternity. Eternal and unchanging things.

B. Things have $\left\{\begin{array}{c}1 . \text { By a supernat- } \\ \text { an origin. agency. } \\ \text { 2. By a natural } \\ \text { agency. }\end{array}\right\}$ II. Hypothesis of creation. Things created, but ever (a) Unchanging unchanging.

III. Hypothesis of spontaneous general creation. Things are a result of a sudden transformation.

IV. Hypothesis of evolution. Things are a result of
gradual development.

Before going further, let me name four standard works which may be consulted for more detailed study:

1. The important article of the celebrated historian of Greek philosophy, Ed Zeller, "Über die griechischen Vorgänger Darwin's," which was published in Abhandlungen der Berliner Akademie, 1878.

2. The work of the American paleontologist, H. F. Osborn, "From the Greeks to Darwin, An Outline of the Development of the Evolution Idea," 1894.

3. "La philosophie zoologique avant Darwin," 1885, by Edmond Perrier.

4. The excellent article, "Evolution," which appeared in the last edition of the Encyclopedia Britannica.

Among the different philosophical systems of India, only three de serve mention here. There is first, orthodox Brahminism, which presents the idea of emanation, by which is meant the eternality of things; then we find the system of Sankya, which combines emanation with a mechanical and evolutionistic explanation of the world; and lastly, there is the system of Buddha which is the philosophy of the spontaneous generation of the world.

Among the Greeks the germs of the evolutionistic idea are found even in the early speculations about the cosmos put forth by Hesiod 
and the Orphics. But Thales is the first who clearly conceives the natural origin of the world when he teaches the existence of a primordial material from which everything is derived. His disciple, Anaximander, goes much further; he is the first declared exponent of the evolutionistic idea; he teaches the gradual development of the world from an unknown material, and a regular succession of periods of the evolution and dissolution of the universe. He also teaches the evolution of the earth, and he supposes a spontaneous generation of organisms in the water (men, themselves, first appeared in the form of fishes). Anaximenes and Diogenes of Appolonia also admit the successive periods of the evolution and dissolution of the universe; while the doctrine of Pythagoras and the Pythagoreans, although insufficiently known, seems to be that of the eternality of the world. Heraclitus adds to the idea of successive periods of evolution and dissolution of the universe, his doctrine of perpetual change. But it is in the doctrine of Empedocles that the evolutionistic idea reaches its height among the pre-Socratic philosophers. Being himself a supporter of the idea of successive periods of evolution and dissolution of the universe, he also conceives this world evolution process as going on in a mechanically causal way and he explains this as the interaction of the four elements and the two forces which unite and separate them. According to his belief, also, organisms arise from a process of spontaneous generation, but he held that it is never complete organisms which are formed, but only parts of organisms, called organs. When they unite, these parts at first form organic combinations incapable of living and propagating themselves, and it is only after a series of successive creations of this kind that organisms finally appear which are capable of self subsistence. The founders of atomism, Leucippas and Democrites, took over the essential features of Empedocles' doctrine, and perfected the mechanical side of it by their doctrine of atoms.

Finally, Anaxagoras, the last of the pre-Socratic philosophers, is the only one of these, who, while admitting an infinite number of elements all different in quality, also supposes chaos as the initial state of the world, and that this world developed itself out of chaos when it received from God the first impulsion. Anaxagoras is also the first who teaches the peculiar doctrine of the eternality of organic germs.

The teachings of Plato concerning the world and organic species, which he conceives clearly for the first time by means of his doctrine of ideas, is very little understood on account of the allegorical form which Plato generally gave to all his doctrines, and especially to his theory of the creation of the world in his "Timeon." But it seems to me that the true Platonic doctrine is a system of emanation, in which God and pure nothingness (identical with empty space and matter) are the two opposite poles. 
Aristotle's system is the type of an antievolutionistic one. The inorganic world is eternal, eternally expressing the corresponding thought of the Divine Being. Although the founder of biology taught that all organized beings form a continuous ladder of degrees of perfection (from the most primitive plants to man, the most perfect animal) he conceives this ladder in a purely static manner, since the organized species were, to him, eternal and unchanging. But, on the other side, he admits spontaneous generation, even for organized beings relatively complex. A similar gradation in the domain of the mind is taught by Aristotle.

In post-Aristotelian philosophy Epicurus and his disciple, the Roman poet Lucretius, especially merit our attention. In teaching the infinity of space and of the number of atoms, Epicurus and Lucretius expressly announce that the evolutionary process of worlds has a definite beginning in time. According to them, there does not exist an evolutionary process of the entire universe, but only evolutionary processes in special worlds, separated in the great infinity of space. They conceive these evolutionary processes as taking place in a purely mechanical way, and they try to give, for the first time, a rational explanation of the evolutionary processes of the worlds. They also teach the evolution of the earth. Furthermore, in taking up Empedocles' evolutionary doctrine with regard to the organic world, Lucretius improves considerably upon this theory by teaching the spontaneous generation of entire organisms which appear in a series of beings more and more perfect. But that which most arouses our admiration for the Roman poet and makes the reading of the fifth book of his poem so extremely interesting is his theory of the evolution of the human race, of the human mind, of human society. We feel that we are here almost in the presence of a modern scientist.

Compared with Epicurus and Lucretius, the Stoics are almost reactionaries. They admit, according to Heraclitus, a periodic succession of universes, and they teach-this is their original theorythe eternality of the germs of things which develop in each universe.

'The doctrine of the Neo-Platonists, Plotinus and Proclus, is the theory of the eternality of the world, which came forth by a process of emanation out of the supreme being, the pure oneness.

In the middle ages, we find in St. Augustine an allegorical interpreter of the origin of things; St. Augustine supposes that inorganic matter was created by God and given the power of selfdevelopment through its own efforts to an ordered inorganic world. He teaches in addition the eternality of the organic germs created by God. St. Thomas Aquinas accepts the doctrine of St. Augustine, although in a manner somewhat disguised.

Among the Arabian philosophers, Avicennus is devoted to the Neo-Platonic doctrine of emanation; he especially teaches, however, 
the slow evolution of the surface of the earth. Averroès is an interpreter of Aristotle in evolutionistic sense. But, in general, the Arabian philosophers and naturalists are faithful disciples of Aristotle.

During the Renaissance, Giordano Bruno, although quite modern in his theory of the infinitude of the universe, does not declare himself clearly upon the question of an evolution in the universe. He teaches the evolution of the earth's surface, but he stands with Aristotle in regard to the organic world. The Jesuit, Father Suarez, is the first man who set forth in a perfectly clear manner, the doctrine of the special creation of organic species, a theory which will play an important part in the discussion of modern naturalists.

Among modern philosophers, Francis Bacon is the first to put forth the question of the possibility of a transformation in the various species, without in any way admitting sympathy with the idea of transformationism. Descartes teaches the evolution of the inorganic world (the steller system, the solar system, the earth), but he quite neglects the question of an evolution in the organic world.

G. W. Leibnitz is interesting on account of several of his doctrines. He formulated these:-1. The famous principle of continuity, which he defines in regard to the organic world in the following terms: "The different species of animals are all parts of a single chain whose links are so intimately fastened together that it can not be determined, either by observation or by imagination where one link ends and the next begins"; 2. Leibnitz teaches the eternality of organic germs; 3 . He formulates the principle of an immanent evolution of the mind (from the monad); 4. He expresses hypothetically the principle of a world evolution, when he says in a passage in his "Theodicee," that it might be true, that the universe was ever progressing from good to better. In opposition to Leibnitz, the metaphysical system of Spinoza, like that of Aristotle, is the type of an antievolutionistic system, the material world and the spiritual world being both, according to Spinoza, the two eternal attributes of the divine substance.

Among the philosophers of the English empirical school we must first mention David Hume, who admits the possibility and even the probability of the doctrine of evolution in opposition to that of creation. But Erasmus Darwin, the English naturalist, goes even further than Hume; he openly takes up the theory of organic transformation and he sets forth an elaborate system of ingenious explanations. A little before him, the celebrated English geologist, James Hutton, had developed for the first time the doctrine of the slow and uniform evolution of the earth's surface.

Kant, the great creator of critical philosophy, engages our attention by several of his doctrines. To begin with, he tried to develop 
for the first time in a scientific or at least partly scientific manner the doctrine of the evolution of the stellar system and, before Laplace, that also of the solar system. Then he went on to discuss the doctrine of organic evolution; but, not being able to overcome the difficulty of explaining this evolution through mechanical causes, he declared himself against it. He admitted, nevertheless, and defended the social and intellectual evolution of humanity.

Herder, a contemporary of Kant, is an even stronger supporter of the idea of evolution, although he recognizes the possibility of the intellectual and social evolution only. But even before Herder the idea of evolution and of progress had been introduced into history by the Italian, Vico, in his famous work, "Principii di Sciencia Nuova," 1725.

In contrast to the majority of German and English thinkers, we find in France, in the eighteenth century, many philosophers and scientists who are more or less devoted to the idea of organic evolution. The celebrated astronomer and mathematician, P. L. M. de Maupertuis, is the first among modern thinkers who, in his article, "Système de la nature: Essai sur la formation des Corps Organisés," 1751 , came out as a definite supporter of the doctrine of transformation, while he at the same time set forth the hypothesis of organic particles and of the spontaneous generation of organic life. D. Diderot follows the doctrine of Maupertuis, but he links it with the theory of organic germs and with Empedocles' teaching about imperfect organisms. However, Diderot is of some interest on account of his doctrine of social evolution. B. de Maillet teaches the metamorphosis of aquatic animals into terrestrial ones; but according to him aquatic animals come from indestructible germs. He also speaks of the slow evolution of the earth's surface, and because of this doctrine he is, like Hutton in England, a precursor of Lyell.

Ch. Bonnet is an antievolutionist. While admitting the principle of continuity held by Leibnitz he deduces from it his famous "ladder of beings." He teaches the eternality of organic germs which develop into complete organisms; each germ is merely the organism in miniature which grows only as it develops itself. (This is the theory of evolution held by Bonnet in contrast to the "theory of epigenesis.") Bonnet, in opposition to de Maillet, is also a supporter of the theory of cataclysms in the history of the earth.

I. B. Robinet admits, as Bonnet does, the Leibnitzian principle of continuity and widens its scope by formulating a "ladder of beings" which includes both inorganic and organic things. He also teaches the eternality of organic germs, but he opposes the theory of cataclysms. 
Buffon begins by being an adherent of the idea of fixity of species; but later, he has a partial glimpse of their transmutability. The great Swedish naturalist Linnaeus formulates, on the contrary, the theory of the fixity of species, teaching that there are "as many species as there came couples from the hands of the Creator".

But it was in France at the end of the eighteenth century that the doctrine of inorganic evolution was elaborated for the first time in a scientific manner by the mathematician and astronomer Laplace; he, however, limited his doctrine to the solar system (in a note to his work, "Exposition du système du monde," 1796).

The French thinkers of the eighteenth century, Turgot and Condorcet, also hold an important place in the development of the theory of social evolution.

The great German philosophers of the commencement and of the first half of the nineteenth century were in general opponents of evolutionism. Schelling's philosophy of identity supposes in nature a series of gradations beginning in inorganic forces passing through organic beings, and finishing in self-conscious mind. But these gradations, according to him, are all in existence simultaneously. Hegal admits Schelling's antievolutionistic point of view as to nature (the inorganic and organic world) - nature being, according to his idea, the externalization of the idea, the essence of which is only a purely logical process of conceptual evolution. But in the domain of mind, Hegel expressly recognizes temporal evolution, and he is one of the most important proponents of the intellectual and social evolution. (His work "Philosophie der Geschichte" is a work which marks a date in the history of this evolution.) Schopenhauer is still more reactionary than Hegel; he declares himself a resolute opponent of evolution in the domain of nature (where he recognizes only degrees of objectivation of the will) as in those of the mind and of history. He also admits in geology the theory of revolutions.

Among the disciples of Schelling, on the contrary, some are declared sympathizers with the doctrine of organic transformation. First, Oken, who advances the theory of cells by his doctrine of infusorian spheres (these becoming animals in the water and plants in the air); these spheres, according to Oken, being the immediate product of the primitive jelly. Immediately after him came Tréviranus who, even before Oken and at the same time as Lamarck in France, had developed the doctrine of organic transformation (in his work, "Biologie oder Philosophie der lebenden Natur," 6 Bde, 1802-1822). Oken and Tréviranus were as distinguished naturalists as philosophers, and they are the only philosophers who, as original thinkers, clearly conceived and maintained the doctrine of organic evolution. 
Goethe, the great poet, was never a declared advocate of organic transformation, although he discussed it during his last years under the influence of the French transformationists. E. ron Baer, the celebrated founder of embryology, became, especially after Darwin, a convinced transformationist; indeed he came very near recognizing evolution as a universal process.

At the beginning and in the first half of the nineteenth century, the doctrine of organic evolution was developed by the scientists in France in a manner much more definite than in Germany. It is especially Lamarck who contributed the most to this development in his "Philosophie zoologique," 1809, and in some earlier essays (the first one is dated 1801). Discussing the idea of species, Lamarck directs special attention to the artificial nature of this idea; to the numerous transitions from one species to another; to the fact of varieties and the connection of these varieties with different external circumstances; to the short duration of the life of existent species so far as we can establish the stability of these species. These are the principal arguments which he presents in favor of transmutability of species. While insisting upon the slow but continuous evolution of the earth's surface, he gains a partial idea of the direct connection which exists between this evolution and that of the organic world. But it is especially in the exposition of the causes of organic evolution that the work of Lamarck presents an extraordinary originality; a part of his work which we can not discuss here.

Geoffrey Saint-Hilaire united with his theory of the unity of plan, the doctrine of organic transformism, attributing the cause of these transformations to the ambient world.

But while Lamarck and Geoffrey Saint-Hilaire represent the doctrine of transformism, the opposing doctrine, that of the creation of species, has nowhere found advocates more enthusiastic and distinguished than Cuvier and Agassiz.

When once this last doctrine had been expressly introduced into natural history by the Swedish naturalist Linnaeus, Cuvier set himself to demonstrate it by observed facts. In linking the doctrine of fixity of species to that of the successive revolutions of the globe, he taught a series of successive creations of species; but, according to him, some of these species are not exterminated by the revolutions, and there have always been migrations of some species that survived. Above all, Agassiz became the typical advocate of the creation theory, teaching that God produced, in different geological periods, organic species more and more perfect, which, once created, remained unchanged.

Auguste Comte, founder of the positivist philosophy, although a resolute advocate of the intellectual and social evolution-especially 
evidenced in his celebrated law of three stages-also remained a declared opponent of organic transformation.

Finally, at the beginning of the second half of the nineteenth century, Darwin succeeded in definitely establishing the doctrine of organic transformation in his celebrated work, "Origin of Species," 1859. The arguments brought forward by Darwin in support of this doctrine are so numerous and for the most part so original that they place this scientist quite above Lamarck, and it is not at all astonishing to see that the doctrine of transformation was adopted by the scientific world only after his vigorous and decisive arguments were published. Just as remarkable as this reasoning is the theory of natural selection which Darwin proposed (at the same time as Wallace) to support his theory of the evolution of the organic world; but upon this point the principle of Lamarck is perhaps of equal importance with that of Darwin. Darwin also holds an important place in the development of the theory of intellectual and social evolution through his work on the origin of man, "The Descent of Man," 1871.

Before Darwin, the great English geologist, Lyell, definitely destroyed the theory of cataclysms in geology and introduced instead the theory of slow and continuous changes due to agents still in action to-day at the surface of the earth. But after the triumph of the Darwinian theory of transformation, the idea of evolution was definitely adopted by geologists in a more precise sense than that of Lyell.

It was only when the doctrine of organic transformation was proposed and elaborated by Lamarck and Darwin that the philosophers began to glimpse the universal importance of the principle of evolution. Herbert Spencer was the first to grasp this importance, and while giving the formula of a general law of evolution, he applied this formula to the entire field of empirical reality, and even to the totality of things in the universe, but he never tried to examine the conditions necessary to a total evolution of the world.

Ed. Hartmann was the first among speculative philosophers to set forth clearly, in his celebrated "Philosophie des Unbewussten," 1869, the problem of the world evolution, and while determining some of the essential conditions of that evolution, to try to give for the first time a positive solution of this problem.

Finally, H. Bergson, in "L'Évolution Créatrice," 1907, tried to state the principle of world evolution as identical with that of organic evolution, and with the actual duration of psychic time. Thus Bergson's doctrine is an example of a phenomenon which is not at all rare in the history of general ideas, a universal truth which has been found and elaborated according to scientific research (Laplace, La- 
marck, Lyell, and Darwin are the four greatest scientists who devoted themselves to this research) ends by being proclaimed by a philosopher as, so to speak, a logical necessity.

As the present short outline of the historical development of the idea of evolution shows, this idea has been established much more by scientific research than by philosophic speculation. And while the inorganic evolution was recognized by some of the Greek philosophers and by Descartes and Kant, the idea of organic evolution was never an integral part of any of the great systems of philosophy, and no great philosopher before Darwin had recognized the general and universal bearing of the idea of evolution. It is a rather extraordinary fact that an idea of an eminently philosophic importance, such as the idea of universal evolution, should never have been recognized as such until after science had demonstrated itthis is a bit humiliating to philosophers; and it shows us that human knowledge, if it wishes to attain its total unity, must find its support and its inspiration as much in scientific research as in pure speculation. 

